\title{
A Review of Factors Affecting E-Learning Systems Adaptation in Higher Education
}

\author{
Mohammed Sani Suleiman ${ }^{1}$, Usman Musa Zakari Usman² \\ ${ }^{1}$ Post Graduate Centre, Limkokwing University of Creative Technology \\ ${ }^{2}$ Faculty of Computing, University Technology Malaysia
}

\begin{abstract}
In today's world of internet technology, Universities throughout the world are focusing on E-learning systems. These universities are involving E-Learning in their educational system not only to bring innovation in traditional teaching methodologies but also to improve their students' learning experience and performance. E-learning is an innovative way of teaching, making the distant learning possible. Therefore, it provides a strong challenge to the traditional learning with its unique advantage E-Learning is a newly developed concept for the people, therefore both aptitude and attitudes of people towards its application and implementation have not been fully studied yet specially in south Sahara Africa. For better understanding and implementation of E-learning adaptation behavior, E-learning providers should be enabled to offer courses that are more in demand by future E-Learners. E-Learning system can be made successful through the understanding of certain earlier factors which influence the student's acceptance and usage of this system. The basic purpose of this study is to identify and analyze the current E-Learning environments. This study involves their characteristics, advantages, limitations and the factors which affects the acceptance of these technologies. Therefore, it is deduced that a successful E-learning system should focus on social, personal, cultural, technological. organizational and environmental factors.
\end{abstract}

Keywords: e-learning systems, higher education, literature review, adoption

\section{Introduction}

The excessive use of internet can be declared as the main reason for the emergence of online learning or electronic learning. E- Learning is considered to be a self-directed teaching E-learning method which is very much modern in its spirit. E-learning is any learning that is executed using electronic mode of communication, based on communication technology. E-learning applications and processes may be one of the web-based learning, computerbased learning, virtual learning opportunities and digital collaboration [3].E-Learning is basically both self-directed and collaborative learning based on web technologies[3]. For providing information about education and training, E Learning uses telecommunication technology [4].In other words, E-learning provides a learning environment or more precisely speaking, learning platform based on internet with the purpose of encouraging and motivating both the learners and instructors to help and cooperate with each other to improve learning. E-learning platforms or environments are named as Learning Environment System (LMS), Content Management System (CMS), Virtual Learning Environment (VLE), sometimes also called Knowledge Management System (KMS) and content authoring tools [5].

In this review, we willuse the synonym "e-learning" to refer to web-based learning systems and "e-product" to refer to a software tool, platform or environment for e-learning system where needed.

\section{Literature Review}

Although E- Learning is growing rapidly in the educational field with its perceived benefits, the efficiency of $\mathrm{E}-$ Learning can be fully utilized only when the users fully accept and use the system. Therefore, the willingness of the students for adopting and accepting the technology is necessary for the successful implementation of E-Learning tools [5]. In order to improve students' learning experience, it has become necessary for the practitioners and policy makers to fully comprehend the factors which affect the users' acceptance of web based learning system.[6]

It has been identified through recent studies that implementation of E-learning is not just a technological solution but it is a process of many different factors such as social factors, and individual factors, organizational such as facilitating conditions in addition to behavioral and cultural factors [7]. These factors play a pivotal role in the development and usage of information technology [8]. [9] Studies shows how proceedings of scientific conferences can be used for trend studies in the field of e-learning. [11] made a significant contribution to the diffusion of digital media in higher education.According to the researchers, over the time span of seven years the complete and deep analysis of frequency distribution reflects the intensity of scientific discussion towards the trends of E-Learning, thus introducing the conclusions about the didactical or technical potentials of innovations [12].More precisely, they observed that, the development potential of learning management, mobile learning, virtual worlds, e-portfolio, social media and massive open online courses are significant for learning in German higher education. [12] Highlights how e-learning tools impact students' achievement. Nearly 2000 students attended the study. The study of the author was compared with that of no provision of E-learning tools. The author' study compares the results of questions from the area of law where the tool was provided in a pilot version with that of the results of questions where the e-learning tool was not provided. It was found by the researchers that E-learning tools affects the students' results. However, it disapproved the idea of E-learning tool bringing negative affect on the students who rely on the given materials. [12] Explored the factors of mobile learning (m-learning) approaches which can be used for enterprise resource planning (ERP) system.

Volume 6 Issue 7, July 2017 


\section{International Journal of Science and Research (IJSR) \\ ISSN (Online): 2319-7064}

Index Copernicus Value (2015): 78.96 | Impact Factor (2015): 6.391

TAM, the technology acceptance model was used to assess the acceptance, perceived ease and usefulness of m-learning. It was found by the researchers that E-learning system was positively correlated for perceived ease of use and perceived usefulness.These findings confirmed other studies which focused on the significance of the quality of course content in e-learning and E-learning projects.

In a nutshell the platform was a tool of great potential, but to be competitive; realities need further improvements. [13] aimed to demonstrate the features and benefits of the practices of e-education in general and in particular in the pharmacy, where e-education helps to clarify the vehicles of pharmaceutical and elements of vehicles would facilitate the process of analysis and helps to count the number of elements, a more precise and faster, where there are a number of theories that helps to clarify it more broadly. These theories determine the effectiveness of the system and how to explain the overlaps that occur within complex eeducation system and therefore the system's capacity for analysis helps greatly with stunning offers of time effort and cost.

The researchers found that e-learning should be effective at increasing knowledge immediately after training for all topics and in all contexts. For pharmacy education, ELearning was considered to be highly suitable instructional format for pharmacists and pharmacy students. E-education system in universities prove to be helpful as the attendance of the students is marked through computer. E-education has to know the number of absentees and upon request solution is sent and received through it. [14] aimed to clarify the extent of teacher satisfaction of the application of e-learning program among persevere teachers. [15] Investigate the key drivers of teachers' e-learning satisfaction, 837 participants in a postgraduate diploma in education completed a survey questionnaire to measure 6 constructs (tutor quality, perceived usefulness, perceived ease of use, course delivery, facilitating conditions and course satisfaction). Data analysis through structural equation modeling showed that, apart from facilitating conditions, all other constructs were significant predictors of e-learning satisfaction. Nevertheless, the facilitating conditions construct was found to be a significant mediator of perceived ease of use and satisfaction.

\subsection{Performance Expectancy (PE)}

Performance Expectancy (or perceived usefulness as defined in the original TAM) is the degree to which a person believes orexpects that using a technology could enhance his performance and be useful for him or her [4]. In our case, performance expectancy represents the degree how a person believes that e-learning systems will increase his performance and change his behavioral intention (BI) to use such systems. Many studies in developing world context found that performance expectancy represents a strong predictor for BI [5].

\subsection{Effort Expectancy (EE)}

Effort expectancy is representing the degree to show how much effort the user needs to put to use the system [8]. In other words effort expectancy represents the perceived ease of use in the original TAM model. [3] Postulate that there are significant differences in the influence of effort expectancy on customer's willingness to use online banking associated with age and gender differences. As a matter of fact, many learners in developing countries are not exposed to many information systems therefore this construct is an important determinant of learning behavioral intention to use such systems [9].

\subsection{Hedonic Motivation (HD)}

Broadly observing, Hedonic motivation has beenseen as way to measure user's perceived enjoyment, fun, and perceived entertainment [10]. The systems which the users think and feel are more joyful and fun filled will be more appealing to them. Previously, [9] examined Hedonic motivation as an enjoyment or happiness resultant from using a technology and found that this factor can play significant part in determining new technology adoption. As people are from different courtiers or from different background and demographics, therefore Hedonic motivation can vary [16]

\subsection{Habit (HB)}

Individual habits can influence user's behavior significantly. People who are in habit of using technology and systems are believed to have more potential to adopt new technologies even prior to using the technology [7]. However, results from some studies did not report positive effects on behavioral intention. For instance, [15] support any positive effect for habit on behavioral intention.

\subsection{Social Influence (SI)}

[16] Defined social influence, as "the degree to which an individual perceives the importance of others opinion for using the new system". Many studies have stressed theimportance of others opinions in shaping ours. However, thesestudies gave mixed results. In fact, the impact of social influence on intention mixed results can be attributed to many factors related to study, users age, culture and so on [15]. Thus, as our study was in developing country, examining such factor becomes significant to understand its influence on users' intention to use e-learning systems.

\subsection{Trust (TR)}

Throughout the literature of technology acceptance, trust has received considerable attention either directly or indirectly and has strongly been considered as a key determiner of user's behavior intention to use technology [15]. According to [9], Trust can be defined as "individual's willingness to accept vulnerability on the grounds of positive expectations about the intentions or behavior of another in a situation characterized by interdependence and risk". Trust can play a significant role in user behavioral intention to use a technology.

\subsection{Behavioral Intention (BI)}

[11], defines behavioral intentionas the degree to which a person is prompted to accomplish certain behavior. In this 


\section{International Journal of Science and Research (IJSR) \\ ISSN (Online): 2319-7064}

Index Copernicus Value (2015): 78.96 | Impact Factor (2015): 6.391

study, we argue that behavioral intention can be determined through different factors including Performance expectancy, Effort expectancy, Hedonic motivation, Habit, Social influences. All these factors have been well established in literature [13] and found to have a positive effect on actual use of technology [14]. Moreover, as behavioral "intention to reuse" can be appropriate indicator for understanding the successful use of a technology [13], we argue and believe that behavioral intention is a valid indicator for the actual use of the e-learning system.

\subsection{Facilitating Condition}

Facilitating conditions, may be defined as "the degree to which an individual believes that an organizational and technical infrastructure exists to support the use of the system"[14]. Facilitating conditions are basically the factors in the environment that influence a person's desire to perform a task whichincludes technical support, skills training, and access to information or resources [15].Facilitating conditions can directly predict and influence the actual usage of computers and systems [16].

\section{Discussion and Conclusion}

An understanding of the factors (barriers and facilitators) influencing e-learning implementation, adoption, scalability, sustainability and educational attainment is necessary for further development and improvement of implementation strategies. The findings of this review will be beneficial for the planning and design of effective e-Learning for family medicine specialty training and education and the development of e-learning guidelines. Moreover, gaps will be identified in literature to inform future research and policy development for wider implementation of elearning.Basically this paper analyzed and reviewed critically the literature of E-learning system. It found out few of the most influential factors in the field of information systems research. More precisely, this paper analyzed the origins, characteristics as well as the limitations, weaknesses and strengths of web-based learning systems. Behaviors and attitudes, cultural backgrounds and other demographic characteristics of the students are significant variables that affect the student learning, especially in a collaborative elearning environment. Comprehending these variables is very helpful for the instructors to plan and design such educational activities which are not only meaningful but also promotes students' knowledge and make E-learning more appealing.Basically, this research can prove to be helpful for the better understanding and helpful for the policy makers to comprehend what the students require and need from Elearning management systems. At the same time, it can prove to be helpfulfor the managementto achieve the most effective deployment of such system and also helps them improve their strategic decision making about technology in the future. It can help them to choose the best approach that is suitable for their students before implementing any new technology.

\section{References}

[1] Bo Cheng, Minhong Wang, JurgenMoormann, Bolanle A. Olaniran, Nian-Shing Chen, (2012), The effects of organizational learning environment factors on elearning acceptance, computer \& Education 58 (2012) 885-899, doi:10.1016/j.compedu.2011.10.014.

[2] Mitjadecman, (20150 modeling the acceptance of acceptance of e-learning in mandatory environments of higher education: The influence of previous education and gender, Computer in human behavior, computers in human behavior, volume 49, August 2015, Page 272281, http://dx.doi.org/10.1016/j.chb.2015.03.022.

[3] Eric Ansong, Sheena LoviaBoateng, Richard Boateng John Effah, (2016), Determinants of e-learning adoption in universities: Evidence from a developing country, $201649^{\text {th }}$ Hawaii international conference on system sciences, doi: 10.1109?HICSS.2016.06.800.

[4] Salem alkhalaf, stevedrewa, rayed alghamdib, osamaalfarraj, 2012), e-learning system on higher education institutions in ksa: attitudes and perception of faculty members, procedia - social and behavioral sciences 47 (2012) $1199 \quad-\quad 1205$, doi: 10.1016/j.sbspro.2012.06.800

[5] Mohammad khasawneh, (2015), factors influence elearning in Jordanian universities academic staff perspectives, procedia social behavioral sciences 210 $\begin{array}{llll}\text { (2015) } & 170 & - & 180,\end{array}$ http://creativecommons.org/licenes/by-nc-nd/4.0/

[6] Dalton Kisanga, GrenIreson, (2015), Barriers and strategies on adoption of e-learning in Tanzania higher learning institutions: Lessons for adopters, international journal of education and development using information and communication technology (IJEDICT), 2015, vol.11, issue 2, pp. 129-137, http://files.eric.ed.gov/fulltext/EJ1074165.pdf.

[7] Ivana ogrizakbiskupic, stjepanlackovic, kresimirjurina, (2015), successful and proactive e-learning environment fostered by teachers motivation in technology use, Procedia - Social and Behavioral Sciences 174 (2015) 3656 - 3662, http://creaticecommons.org/licenses/bync-nd/4.0/.

[8] Lea SorillaNisperos, (2014), Assessing the E-learning readiness of selected Sudanese universities, Asian journal of management science and education vol. 3(4) October 2014, http://www.ajmse.leenaluna.co.jp/AJMSEPDFs/Vol.3(4)/AJMSE2014(3.403).pdf.

[9] T. ketema, M Nirmala PhD, (2015), The impact of elearning to enhance quality of education: The case of adama science and technology university, African journal of computing \& ICT (2015) ISSN 2006-1781, https://static.secure.website/wscfus/5655211/4508267/v 8n1p16-2015-ajocict.pdf.

[10] Ivana simonova, (2014), e-learning in mind maps of Czech and Kazakhstan university students, Procedia Social and behavioral sciences 171 (2015) 1229-1234, http://creativecommons.org/licenses/by-nc-nd/4.0/.

[11] Geoffrey kituyi, Irene tusubira, (2013), a framework for the integration of e-learning in higher education institutions in developing countries.

[12] http://files.eric.ed.gov./fulltext/EJ1071350.pdf, international jpurnal of education and development unsing information and teclecommunication technology IJEDICT.

[13] Ulisses Miranda azeiteiro, paulabacelar-nicolau, Fernando j.pcaetano, Sandra caeiro, (2014), education

\section{Volume 6 Issue 7, July 2017




\section{International Journal of Science and Research (IJSR) \\ ISSN (Online): 2319-7064 \\ Index Copernicus Value (2015): 78.96 | Impact Factor (2015): 6.391}

for sustainable development through e-laerning in higher education: experiences in Portugal, journal of cleaner production $\mathrm{xxx}$ (2014) 1-12, http://dx.doi.org/10.1016/j.jclepro.2014.11.056.

[14] Jintaveekhlaisanga, maneeratlikhitdamrongkiatb, (2015), e-learning system in blended learning environment to enhance cognitive skills in for learners in higher education, procedia - social and behavioural sciences $\quad 174 \quad$ (2015) 759-767, http://creativecommons.org/licenses/by-nc-nd/4.0/.

[15] Pierre gedeon, lionelkhalil, (2015), management of the transition to e-learning in higher education based on competence quotient, international conference on communication, management and information technology (ICCMIT 2015), http://creativecommons.org/licenses/by-nc-nd/4.0/.

[16] Mohammed hussainthowfeek, azizahjaafar, (2013), an investigation of the factors that influence student's intention to adopt e-learning, IVIC 2013, LNCS 8237, pp. 742-753, doi:10.1007/978-3-319-02958-0_67,

[17] Salem alkhalaf, steve drew, thameralhussain, (2012), assessing the impact of e-learning systems on learners: a survey study in the $\mathrm{ksa}$, procedia - social ansbehavioural sciences $47 \quad$ (2012) 98-104, doi:10.1016/j.sbspro.2012.06.620.

[18] Hosseinmohammadi, (2015), factors affecting the elearning outcomes: an integration of tam and is success model, telematics and informatics 32 (2015) 701-719, doi:10.1016/j.tele.2015.03.002.

Volume 6 Issue 7, July 2017 www.ijsr.net 